\title{
The Interactions of State and Business Structures on Formation of Competitive Educational Environment in Russia
}

\author{
Elena Lylova \\ Department of Public Administration \\ Peoples' Friendship University of Russia \\ (RUDN University) \\ Moscow, Russia \\ lylova_ev@rudn.university
}

\author{
Marina Ignatskaya \\ Professor \\ Peoples' Friendship University of Russia \\ (RUDN University) \\ Moscow, Russia \\ ignatskayam@mail.ru
}

\begin{abstract}
The proposed article updates modern critical perspectives on relationships, interactions, feedback loops and the formation of interactions within the triad of "state - society business structures" in terms of governing the subject-object optimization effects. While the focus is put on the whole system of education (higher vocational and additional vocational for adults) for the preparation of competitive specialists-managers of social management (in public and business administration field) in modern Russia, taking into account national socio-cultural characteristics, as well as accumulated foreign progressive experience. The basic aim of this article is to identify effective approaches to implement interactions of public authorities, businesses and higher school institutions in the preparation and job placement of graduates in the field of social governance in Russia. For the above declared aim we actively use such methods and approach to the conduct of modern research, as an ascent from the concrete to the abstract, the method of generalization, quantitative changes transition into the qualitative, movement from particular to general, analysis and synthesis. The basic result of this research is that a fundamental reversal of domestic systems of higher vocational education and additional vocational adult education to the direction of a Russian employer practices and needs is possible only on the basis of continuing professional education programs funded by the state, in conjunction with employers a qualitatively new level of educational programs, performed in the spirit of social innovations on the basis of modern interactive educational technologies, as well as retraining the entire corps of teachers on the basis of a broad introduction to the Russian educational practice competence, interdisciplinary/ inter-professional and problem-focused approaches.
\end{abstract}

Keywords-higher vocational education; social management; public and business administration specialties; aggregate Russian employer; additional vocational adult education.

\section{ThE DEFINING Role OF THE RUSSIAN STATE IN} SHAPING COMPETITIVE EDUCATIONAL ENVIRONMENT

Conceptual fundamental relations and interactions of society, state and business structures in the current international market context are largely shaped by the theory of new public

The publication was financially supported by the Ministry of Education and Science of the Russian Federation (the Agreement number 02.a03.0008) management (NPM).

Within this type of relationships NPM theory propose that the authorities act as bodies which render services to their clients, i.e. professional activities of public servants and officials deal with the position of providing paid services to the public. Since market economy services are mostly rendered by private enterprises, the applied value of the theory of new public management as opposed to the traditional rational bureaucracy, especially in the context of the Russian sociocultural specificity, carries a wide range of negative effects (today they are widely analyzed by Russian experts in the sphere of social management - Barabashev [1], Narbut and Fedorov [2], Malkovskaya [3], etc.; and foreign researchers Wollmann and Schröter [4], Gagnon [5], etc. Thus, the basic question remains unsettled - that is the question of the principles of mutual power and society relationships, and most importantly, how to make the services affordable for citizens, according to the theory of new public management becoming customers.

From our point of view, the subject-object relationships between state, society and business structures in Russia could not objectively be based even on such a "trendy" theory of the new public management, because really socio-oriented and effectively regulated by the state national economy under modern conditions and on the basis of the positive world experience of the twentieth century is incompatible with the realization of the ideas of market fundamentalism (as it is well known, the movement vector of progressive evolution comes from administrative to market forms and methods of control only under the current regime of civil society, the rule of law and the working principle of separation of powers, as well as in conditions of economic democracy ("participative economy"). In a civilized society economic democracy within the triad "society - state - business" actually provides their equidistance as the key concept and category, as well as the public good as the highest social value. In Russia we have so far, priority is given to business, especially big one, with direct serving of its interests by the state and the authorities on the basis of widespread corruption, with the result that the public good is minimized through economic egoism of elite circles. 
In terms of strategic orientations for the system of public administration development particular importance in modern Russia belongs to long-term interactions between local and national (state and society as a whole) levels of management in a constantly growing uncertainty of economic functioning context. The primary role is played by quality management training for professional managers, first and foremost, the managers of the highest level in government and business, since under the unformed conditions of civil society, the socalled "manual mode" of all levels of government with the highest possible defining role of leader personality, his level of professionalism is most widely required and used in practice. Hence objectively, in modern conditions the quality management training of professionals takes the mostly important place.

Only the formation of such intellectual managerial elite is able to overcome the management system total global crisis through the emergence of new innovative forms of statehood (in the spirit of the category of "post-democracy" and promising forms of development of this new reality). As everywhere in the world a weakening of the role of international institutions is taking place, to the extent that the nation-state becomes the only authorized spokesman for the diverse social needs.

In this regard, the specificity of modern Russian socioeconomic transition involves the formation of new education environment, taking into account the objective conditions of its formation in the modern world (our country has lagged behind by the speed of these critical processes by different estimations from ten to thirty years). Nevertheless, albeit with a lag, we go on the way of our higher vocational education (HVE) becoming mass, increasing the proportion of paid education, transition to flexible specialties, the internationalization of educational processes, as well as the emergence of new forms of education and educational technologies [6].

Thus, today the Russian state is able to accelerate the processes of formation of new competitive educational context through focused public policy at least in two interrelated areas:

1) strengthening focused government support (financing) of higher vocational education (HVE) and additional vocational adult education (AVE) systems;

2) full system performance monitoring of public policies, especially in the field of quality management of professional educational services in general, and the quality of faculty (adult educators) scope of HVE / AVE (for adults) in the field of social management in public and business administration majors in particular.

It is essential to bear in mind that according to the most advanced foreign experience (both Western and Eastern) the above directions of activity of the modern state are able to operate at the best value only in case of decision-making and development programs are being worked out by the independent experts-professionals, including major universities and research institutes and organizations and by no means - by governmental officials of all levels. It is obvious that such a system is going to be formed in Russian education environment.
Conceptually and methodologically the essentials of progressive changes in the HVE in social management dimension with the use of the best samples of foreign experience are based on the formation of subject-object relationships within both directions that is in implementing management itself, and in the process of teaching managers in universities [1]. So, in our view, for the training of social management within the specialties of public administration and business administration, especially at advanced master's programs, essential preliminary qualitative selection based on natural inclinations, abilities (among them the key ones - to assume voluntary responsibility and to take immediate managerial decisions adequate to situation), as well as accumulated professional administrative experience (as it is practiced abroad within AVE (for adults) on master of public administration (MPA) programs, primarily involved persons must have special work experience in administration at various levels) is strongly required. In addition, social management training programs definitely the further, the greater are becoming practice-oriented and have interdisciplinary nature, objectively evolving to trans-professional direction, implementing differentiated training levels, as well as a wide range of specializations, - from the political, territorial and legal aspects of social management and up to environmental management.

\section{COMmon MOdern Fundamentals OF PUBlic - \\ PRIVATE INTERACTIONS AND ITS STATUS WITHIN SOCIAL MANAGEMENT SPECIALISTS TRAINING DiMENSION}

To guarantee the quality assurance of training system for public and business administration specialists it is essential to bear in mind the possibilities of finding optimal connection between the requests of labor market concerning skills and professional competencies of specialists presented in summarized views of total modern Russian employer, particularly large, on the one hand, and on the other, providing professional education of higher educational institutions, mainly large state, implementing state education policy through regulatory activities carried out mainly on the basis of the Federal State educational standards. As a basis for improving public impact and regulation of educational processes a generalized view of modern Russian employer on the challenges and opportunities of training in the field of optimization of social management can be taken, because it most closely reflects the accumulated unsettled problems of HVE sphere and corresponds to the needs and demands of today's labor market.

In general, we can point out that the view of modern aggregate Russian employer regarding quality of professional managers training is a total dissatisfaction with the prevailing status quo [7]. Hence the desire is to establish a permanent interaction with universities, particularly with large state, as well as the establishment and development of their own corporate educational institutions. Meanwhile the modern Russian aggregate employer evaluates as satisfactory basic knowledge of a specialty, computer lab, and language literacy of graduates. However, he is extremely negative in the assessment of their business communications skills and individual personal characteristics of graduates, in particular, 
lack of not only skills, but even the very understanding of the need to work in a unified team.

The most successful Russian organizations seek to create synergies with universities on an ongoing basis to tailor educational processes to their needs. In addition, there is another proven by international practice output, namely, the creation and development of their corporate educational institutions.

Russian university graduates have more multidisciplinary specialization preparedness, as compared to the Western HVE as a whole, bearing in mind the breadth of vision. However, our universities still consciously and deliberately do not teach team-building and skills to work in a unified command, in contrast to, for example, American universities, and this is a major negative feature in the eyes of aggregate modern Russian employer [8; 9; 10;11;12]. In addition, according to the aggregate Russian employer, our graduates come in organizations with inflated self-esteem, i.e. they immediately claim to high office and the same high wages, while not submitting their desire to learn on an ongoing basis. The only way to find a job in this case is the readiness of the applicant after explaining the real situation to reduce the level of claims and to consider other options in organization. These are very important qualities in the eyes of aggregate employer, such as sociability, ability to negotiate, flexibility and adaptability, willingness to adapt behavior to the course of events. Then the employer begins to focus on the positive qualities of an applicant.

The Russian managerial education also suffers from separation of professional knowledge of graduates from the practice, which is reflected in their inability to apply the acquired knowledge to solve applied tasks, as well as in sociopsychological unreadiness to the realities of organizationalindustrial relations and in general to the implementation of the governance and leadership. Lack of knowledge about organizational structure, the rules of the game and the chain of command shows that the problem is not just in professional knowledge, but in social incompetence of graduates, i.e. inability to work in the workplace as a team member, inability to manage and assign tasks to subordinates.

Another fundamentally important and requiring its authorization problem acts the perception of the current situation with the overall quality of training in general, by educational institutions and, in particular, by their leaders, that is their disagreement with the low assessment of the quality of its alumni knowledge contrary to the results of the researches. So, from nine major parameters of quality assessment of preparedness for independent professional activity of young professionals, that are: 1) basic knowledge; 2) knowledge of computer and foreign language, 3) knowledge of specialty, 4) self-learning skills; 5) ability to apply knowledge in practice, 6) communication skills, 7) teamwork skills, 8) focus on career and adequacy of self-evaluation, 9) readiness for rapid inclusion into the workflow; at least five (from 3d - to 5th and from 8th to 9th) reflect the maximum divergence in estimates of employers and universities themselves. The situation can primarily be explained bearing in mind the fact that in many Russian universities, except the leading ones, the outdated paradigm of education as a whole still dominates, whereby the priority belongs to a deep theoretical knowledge, followed by fluency in a foreign language, a good preparation in the field of information technology, knowledge in the field of economics, law, sociology and political science. Most part of Russian universities CEOs today do not recognize the seriousness of the problems with the quality of training. Their social behavior is although quite rational because the system itself directs them to a solvent, with archaic attitudes and perceptions, consumer, namely, young students, their parents and the state, while feedback with external environment and business community is either complicated or is completely missing. Thus, administrative system acquires features and characteristics of the closed one - in contrast to the new economy open systems that a priori deprives it efficiency and quality [13].

Since the situation is fairly static, the business community is adapting to it in two ways. Firstly, it purposefully continues to collaborate with universities to modify educational programs, as well as the forms and methods of teaching with the transition to modern interactive educational technologies. Secondly, the business community has been engaged in internal education projects up to corporate universities. Such an approach in its concrete implementation can be considered as cluster HVE reform in Russia.

\section{TRENDS IN CHANGES WITHIN PUBLIC AND BusinESS ADMINISTRATION SPECIALTIES EDUCATION IN RUSSIA}

The main trends of changes objectively taking place in the area of training in public and business administration, is that modern business community increasingly participates not only in training itself, but also in job placement of graduates through the following well-known in the world basic technologies, such as: targeted order for training of specialists; employer participation in selecting graduates; joint organization of students practices; financial assistance by learning organizations to universities; employer participation in training students and teacher training, when the leading staff of the external organizations is engaged in teaching of special subjects, invite professors to their internships, as well as actively participate in shaping of curricula; organization of educational and industrial consortia (within the dimension of university-science-business); and finally, corporate universities. It is the latter that reflect the highest stage of development of their educational trajectories. Corporate universities do not have the original orientation on provision of basic fundamental knowledge, but in return they learn in depth specialty (level of technical skills and competencies), as well as what still is not being taught by modern average Russian higher educational institution, namely, leadership, personal effectiveness assessment, time management, communications skills, career success achievement, etc. (level of human relations skills and competencies). The undisputed advantages of corporate university as the most important modern educational technology already proven in the Russian Federation are the establishment of common training standards, organizing educational and practical programs, and guaranteed opportunity to make a career. Their tasks in addition to training include the formation and management of corporate culture as intangible factor of organizational effectiveness, efficient 
management of intellectual capital, including on the basis of "soft" managerial technologies, as well as management consulting.

Therefore socio-cultural and economic realities themselves have clearly defined the regime of public expectations and requests from the modern Russian universities. It is above all a selection of suitable staff with the highest level of cognitive mobility, as well as with the fundamental basic education (special applied courses and professional practices Russian business organizations are ready to assume).

\section{CONCLUSIONS}

So, interactions between the state and business structures in the field of higher and further education in terms of unsettled topical problems of social management professional training within specialties of public and business administration were highlighted in this article. These very far from its optimal state objectively caused interactions are considered, firstly, through the possibility of improving public administration educational environment and its regulation; secondly, through quality management specialist training in social management based on improving the quality of interactions in this area; thirdly, through teacher (faculty) training quality management of HVE/AVE system in order to strengthen the regulatory impacts of the state on educational processes in contemporary Russia through the prism of the positive foreign experience.

A fundamental reversal of domestic systems of HVE/AVE to the direction of a Russian employer practices and needs is possible only on the basis of ensuring of continuing professional education programs funded by the state, in conjunction with employers a qualitatively new level of educational programs, performed in the spirit of social innovations on the basis of modern interactive educational technologies, as well as retraining the entire corps of teachers on the basis of a broad introduction into the Russian educational practice competence, interdisciplinary, interprofessional and problem-focused approaches.

\section{REFERENCES}

[1] A.G. Barabashev, "Theoretical guidelines for further public service development of the Russian Federation","Public Administration Issues" Journal, vol.1. Russia, Moscow: Publishing House of Hihger School of Economics, 2007, pp.19-52.

[2] N.P. Narbut and Fedorov V.A.,"Subject-object relations in social administration: methodology and training". RUDN journal of sociology, vol.2. Russia, Moscow: Publishing House of RUDN University, 2008, pp.5-14.

[3] I.A. Malkovskaya, "From globalization to sovereignty state: trend to management of competences". RUDN journal of sociology, vol.1 Russia, Moscow: Publishing House of RUDN University, 2008, pp.53-69.

[4] H. Wollmann and E. Schröter,"New Public Management". Handbuch zur Verwaltungsreform. Germany: VS Verlag für Sozialwissenschaften, 2005,pp.63-74.

[5] A.C. Gagnon, "Linking New Public Management with Public Human Resource Management Reform", Journal of Public Administration Research and Theory, vol.26. United Kingdom: Oxford, 2016, pp.823824.

[6] M. Galushkina and V. Knyaginin, Massive, flexible and international. Russia, Moscow: The Expert, vol. 43, 2005. http://expert.ru/expert/2005/43/43ex-obraz_278/ (accessed March 5, 2017).

[7] Center for strategic research "North-West". http://csr-nw.ru/en/ (accessed March 5, 2017).

[8] K.I. Adizes, Leading the leaders: how to enrich your style of management and handle people whose style is different from yours, Russia, Moscow: Alpina Publisher, 2009.

[9] Best articles for ten years. Moscow: Harvard Business Review Russia, 2015. http://hbr-russia.ru/ (accessed March 5, 2017).

[10] S.C. Certo, Supervision, Quality and Diversity through Leadership. Boston, Massachussetts: 2010.

[11] D.Dotlich and P. Cairo, Why CEOs fail: the 11 behaviors that can derail your climb to the top - and how to manage them. Russia, Moscow: Alpina Publisher, 2012.

[12] Office for Standards in Education. The initial training of further education teachers: Findings from 2004/05 inspections of courses learning to national awarding body qualifications. London: 2006. http://www.ofSted.gov.uk/ (accessed March 5, 2017).

[13] M.A. Ignatskaya, "Adult continuing managerial (PA \& BA) education sector's development in Russia and abroad - problems of optimization", RUDN journal of public administration, vol. 4. Russia, Moscow: Publishing House of RUDN University, 2016, pp.67-85. 